\title{
Isolation, purification, and characterization of L-glutamate oxidase from Streptomyces sp. 18G
}

\author{
Supawadee Wachiratianchai \\ Department of Biotechnology \\ Faculty of Science, Mahidol University \\ Rama 6 Road, Bangkok 10400 Thailand \\ Tel: 6622015310 \\ Fax: 6622463026 \\ E-mail: g4236968@student.mahidol.ac.th \\ Amaret Bhumiratana \\ Department of Biotechnology \\ Faculty of Science, Mahidol University \\ Rama 6 Road, Bangkok 10400 Thailand \\ Tel: 6622015310 \\ Fax: 6622463026 \\ E-mail: scabr@mahidol.ac.th \\ Suchat Udomsopagit* \\ National Center for Biotechnology and Genetic Engineering \\ National Science and Technology Development Agency \\ 113 Phaholyothin Road, Klong 1, Klong Luang \\ Rangsit, Pathumthani 12120, Thailand \\ Tel: 6625646700 ext 3423 \\ Fax: $6625646701-5$ \\ E-mail: suchat@biotec.or.th
}

Financial support: Grant PDF/15/2542 from Thailand Research Fund.

Keywords:L-glutamate, L-glutamate oxidase, purification, screening, Streptomyces.

Abbreviations: GDC: Glutamate decarboxylase

GDH: Glutamate dehydrogenase;

GLOD: L-glutamate oxidase.

An extracellular L-glutamate oxidase (GLOD) was purified from soil-isolated Streptomyces sp 18G. The enzyme had a molecular weight of approximately 120,000 and consisted of two identical subunits, each with a molecular weight of 61,000 . The isoelectric point was pH 8.5 and the enzyme had an optimal pH between 7.0-7.4. GLOD showed the maximum activity at $37^{\circ} \mathrm{C}$. The GLOD activity was stable at $\mathrm{pH}$ ranging from 6.5 to 7.0 for $1 \mathrm{hr}$. Among 21 amino acids tested for substrate specificity, L-glutamate was almost exclusively oxidized. D-glutamate and L-aspartate were oxidized but only to extents of $0.79 \%$ and $0.53 \%$, respectively.

L-glutamate is an important amino acid widely used as a food additive because of its taste enhancing property. In neurochemistry, it is a major excitatory neurotransmitter of the central nervous system and the enteric nervous system (Cooper and Pritchard, 1994; Zilkha et al. 1995; Valero and García-Carmona, 1998). Based on this information, it is obviously very important to develop specific analytical methods for measuring this amino acid, preferably in simple and reliable way (Valero et al. 1998).

L-glutamate can be measured by chromatographic methods (Kondrat et al. 2002; Hanko and Rohrer, 2004) which are complicated, time-consuming and require extensive sample pretreatment. The enzymatic method is chosen to overcome the problems mentioned above. Glutamate dehydrogenase (GDH) and glutamate decarboxylase (GDC) have been employed for the determination of L-glutamate (Shi and Stein, 1996; Liu et al. 1999; Ling, et al. 2000; Oliveira et al. 2001; Qhobosheane et al. 2004; Rodriguez et al. 2004). However, the GDC and GDH have some drawbacks due to poor substrate specificity and the requirement for expensive coenzyme such as $\mathrm{NAD}^{+}$. L-glutamate oxidase (GLOD) is used instead due to the relatively high substrate specificity comparing to GDH and GDC and no requirement for additional coenzyme. GLOD is an enzyme that specifically catalyzes the oxidative deamination of L-glutamate in the presence of water and oxygen with the formation of

*Corresponding author 
Table 1. Purification of GLOD from Streptomyces sp. $18 \mathrm{G}$.

\begin{tabular}{|c|c|c|c|c|c|}
\hline Purification step & Total protein $(\mathrm{mg})$ & Total activity (U) & $\begin{array}{c}\text { Specific activity } \\
\left(\mathrm{U} \mathrm{mg}^{-1}\right)\end{array}$ & $\begin{array}{c}\text { Yield } \\
(\%)\end{array}$ & $\begin{array}{l}\text { Purification } \\
\text { (fold) }\end{array}$ \\
\hline Culture extract & 1,203 & 185.25 & 0.15 & 100 & 1.0 \\
\hline Ammonium sulphate & 376.6 & 151.03 & 0.4 & 81.53 & 2.6 \\
\hline SP-SepharoseFF & 10.7 & 70.23 & 6.56 & 37.91 & 42.7 \\
\hline Q -SepharoseFF & 0.72 & 33.43 & 46.48 & 18.05 & 302 \\
\hline Gel filtration & 0.2 & 30.85 & 152.36 & 16.65 & 990 \\
\hline
\end{tabular}

a-ketoglutarate, ammonia and hydrogen peroxide (Kusakabe et al. 1983; Böhmer et al. 1989; Fukunaga et al. 1998). The hydrogen peroxide formed in this reaction can easily be detected by the chromogenic peroxidase reaction or amperometric method (Böhmer et al. 1989; Villarta et al. 1991; Almeida and Mulchandani, 1993; Zilkha et al. 1995; Niwa et al. 1997; Chang et al. 2003). Therefore, Lglutamate oxidase holds excellent potential for use as the principle component in the determination of L-glutamate (Chen and Su, 1991; White et al. 1994; Ye et al. 1995; Matsumoto et al. 1998; Udomsopagit et al. 1998; Valero and Garcia-Carmona, 1998; Yao et al. 1998), although the presently available GLOD still has several disadvantages such as broad substrate specificity of the enzyme from some microorganisms (Kamei et al. 1983) and high cost (Kusakabe et al. 1983). In this study, we conducted a screening for glutamate oxidase-producing microorganisms from natural sources and investigating the physical and biochemical characteristics of the GLOD after the purification steps.

\section{MATERIALS AND METHODS}

\section{Materials}

SP-Sepharose Fast Flow, Q-Sepharose Fast Flow, and Superdex 200 HR 10/30 were from Amershame Biosciences Ltd. (Uppsala, Sweden). Protein markers for gel filtration and amino acids were from Sigma-Aldrich Co. (St. Louis, USA).

\section{Microorganisms and culture conditions}

Streptomyces sp. 18G was isolated from soil sample in Khlong Luang District, Pathum Thani Province, Thailand. The medium used for the screening was humic acidvitamin agar (Hayakawa and Nonomura, 1987). The microorganism grown on inorganic salt starch agar medium (Williams et al.1983) had spiral mycelia with spores. The colonies were tough, leathery and developed to powder and velvet colonies after spore forming. These characteristics suggested that the GLOD producingmicroorganism was of the genus Streptomyces.

\section{Screening methods}

The GLOD producing strain was selected by using the

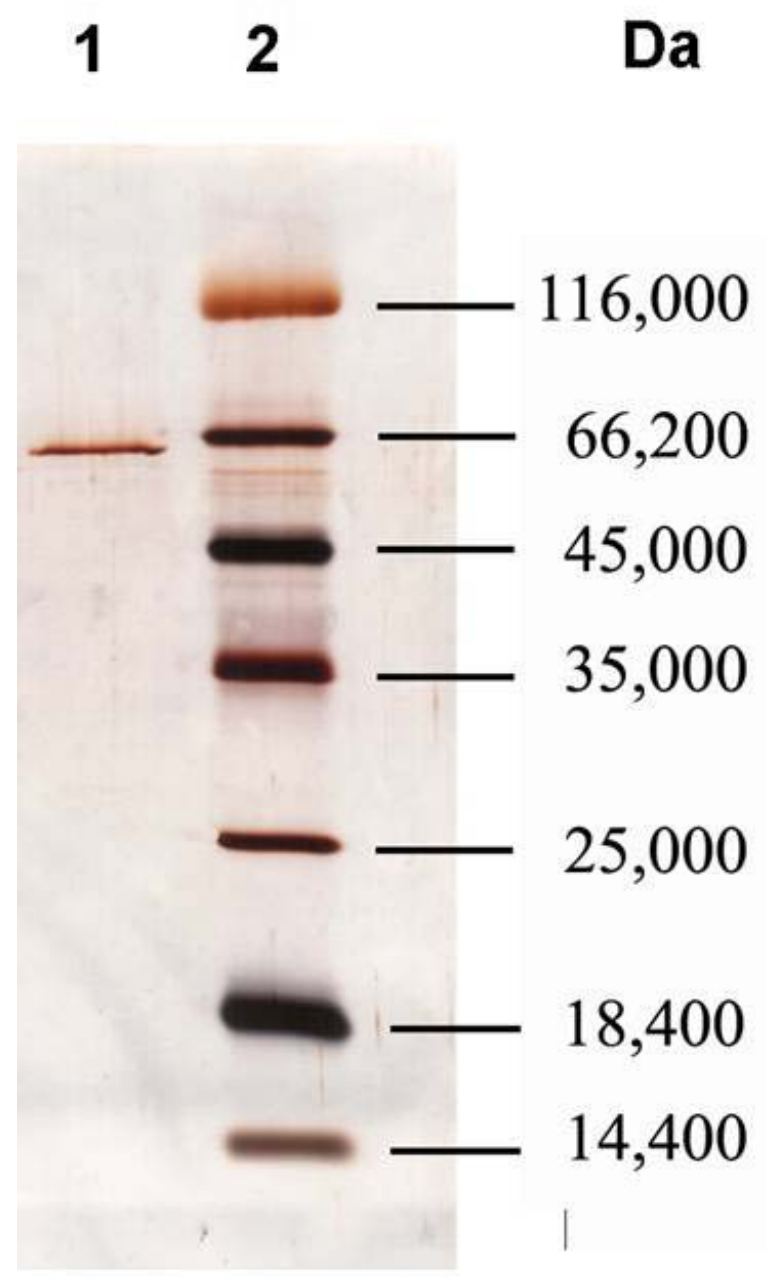

Figure 1. SDS-polyarylamide gel electrophoresis of GLOD from Streptomyces sp. 18G. Lane 1, purified GLOD oxidase; lane 2, marker proteins, lysozyme $(14,400), \quad \beta$-lactoglobulin $(18,400)$, restriction endonuclease Bsp981 $(25,000)$, lactate dehydrogenase $(35,000)$, ovalbumin $(45,000)$, bovine serum albumin $(66,200)$ and $\beta$-galactosidase $(116,000)$. 
Table 2. Substrate specificity of GLOD. The enzyme activity was measured as described in text. All values represent the percentage activity compared with the value obtained from L-glutamate. UD = undetectable.

\begin{tabular}{|c|c|}
\hline Substrate $(10 \mu \mathrm{M})$ & Relative activity (\%) \\
\hline L-glutamate & 100 \\
\hline D-glutamate & 0.79 \\
\hline L-glutamine & UD \\
\hline L-aspartate & 0.53 \\
\hline L-glycine & UD \\
\hline L-alanine & UD \\
\hline L-arginine & UD \\
\hline L-cysteine & UD \\
\hline L-histidine & UD \\
\hline proline-L-hydroxy-4-trans & UD \\
\hline lysine hydrochloride-L & UD \\
\hline L-proline & UD \\
\hline L-serine & UD \\
\hline L-threonine & UD \\
\hline L-valine & UD \\
\hline L-isoleucine & UD \\
\hline L-methionine & UD \\
\hline L-phenylalanine & UD \\
\hline L-leucine & UD \\
\hline L-tryptophan & UD \\
\hline L-tyrosine $(1 \mu \mathrm{M})$ & UD \\
\hline
\end{tabular}

method based on $\mathrm{H}_{2} \mathrm{O}_{2}$-dependent peroxidase catalyzed chromogenic reaction, as described by Li et al. 1996. Filter papers were dipped into the reaction mixture containing 2 $\mathrm{U} / \mathrm{ml}$ horseradish peroxidase (HRP), $10 \mu$ mole monosodium glutamate (MSG), $10 \quad \mu$ mole 4aminoantipyrine (AAP) and $17.5 \mu$ mole phenol in $0.1 \mathrm{M}$ potassium phosphate buffer $\mathrm{pH} 7.4$, prior to placing on the isolated colonies. The reaction was allowed to take place by incubating for 15-30 minutes at ambient temperature without light. GLOD producing colonies that turned the filter paper red were collected.

\section{GLOD production culture}

Streptomyces sp. $18 \mathrm{G}$ was grown in wheat bran precultivation medium described by Böhmer et al. 1989 with some modifications. The medium contained $2.0 \%$ wheat bran, $0.5 \%$ sodium chloride and $0.5 \%$ monosodium glutamate. The culture was grown at $37^{\circ} \mathrm{C}$ with shaking at $200 \mathrm{rpm}$.

\section{GLOD assay}

GLOD activity was assayed following the methods described by Li et al. 1996. The reaction mixture contained $1.0 \mu$ mole 4-aminoantipyrine, $17.5 \mu$ mole phenol, $2.5 \mathrm{U}$ horseradish peroxidase and a sufficient amount of GLOD in $0.1 \mathrm{M}$ potassium phosphate buffer $\mathrm{pH} 7.4$ in a total volume of $1.30 \mathrm{ml}$. After a pre-incubation for $2 \mathrm{~min}$ at $37^{\circ} \mathrm{C}$, the reaction was initiated by addition of $10 \mu$ mole MSG to the reaction mixture. The absorbance at $500 \mathrm{~nm}$ was measured after incubated for $30 \mathrm{~min}$ at $37^{\circ} \mathrm{C}$ with gentle shaking. One unit of enzyme activity is defined as the amount of enzyme required to produce $1 \mu \mathrm{mol}$ of $\mathrm{H}_{2} \mathrm{O}_{2}$ per minute under the assay conditions.

\section{Protein determination}

Protein was determined using Bradford assay. Bovine serum albumin (BSA) was used as a standard.

\section{Purification of GLOD}

Enzyme concentration. Ammonium sulphate precipitation technique was used to concentrate the crude enzyme. Grounded ammonium sulphate was gradually added to the chilled enzyme solution while stirring until $80 \%$ saturation was obtained. The solution was then stirred at $0^{\circ} \mathrm{C}$ for $1 \mathrm{hr}$ The precipitate was collected by centrifugation at 10,000

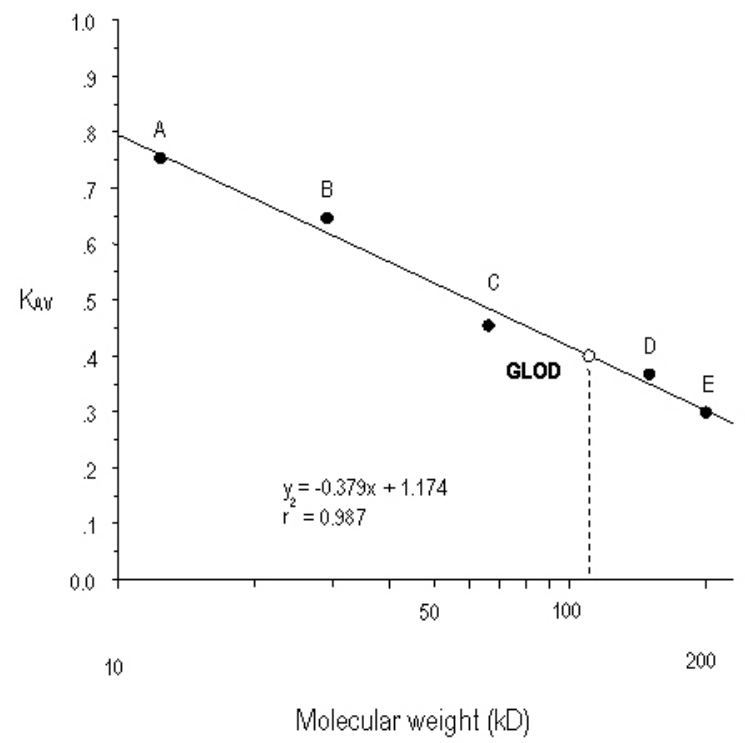

Figure 2. Molecular weight determination of native GLOD by Superdex 200 HR 10/30 gel filtration chhromatography. The molecular weight used were: A, cytochrome C $(12,400)$; B, carbonic anhydrase $(29,000)$; C, bovine serum albumin $(66,000)$; $D$, alcohol dehydrogenase $(150,000)$ and $E, \beta$-amylase $(200,000)$. 


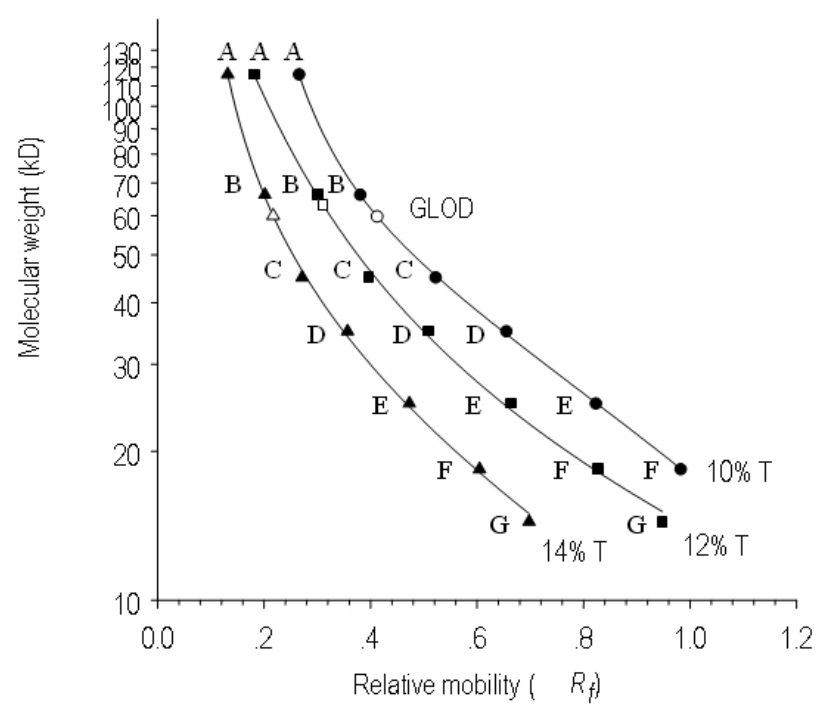

Figure 3. Estimation of molecular weights of GLOD subunits by SDS-PAGE in 3 different polyacrylamide separating gel concentrations, i.e. $10 \%, 12 \%$ and $14 \%$ with $4 \%$ stacking gel. The molecular weight markers used were: A, lysozyme $(14,400)$; B, $\beta$-lactoglobulin (18,400); C, restriction endonuclease Bsp981 $(25,000) ; \mathrm{D}$, lactate dehydrogenase $(35,000) ; \mathrm{E}$, ovalbumin $(45,000) ; F$, bovine serum albumin $(66,200)$ and $G, \beta$-galactosidase $(116,000)$.

$\mathrm{rpm}$, at $4^{\circ} \mathrm{C}$ for $45 \mathrm{~min}$. The protein pellet was dissolved in a minimal volume of $20 \mu \mathrm{M}$ chilled potassium phosphate buffer $\mathrm{pH}$ 6.0. The enzyme solution was dialyzed overnight against the same buffer at $4^{\circ} \mathrm{C}$.

Cation-exchange chromatography. The concentrated enzyme was applied to SP-Sepharose FF column with a bed volume of $30 \mathrm{ml}$. The column was pre-equilibrated with 20 $\mu \mathrm{M}$ potassium phosphate buffer $\mathrm{pH}$ 6.0. After the column was washed with $40 \mathrm{ml}$ of potassium phosphate buffer, the enzyme was eluted with a linear salt gradient of $0-.3 \mathrm{M}$ sodium chloride at a flow rate of $1 \mathrm{ml} / \mathrm{min}$. Each fraction of the enzyme solution was tested for GLOD activity. The active fractions were pooled and concentrated by means of a centrifugal ultrafiltration and kept in an ice bath for further purification steps.

Anion-exchange chromatography. The pooled active fractions were desalted prior to loading into the preequilibrated Q-Sepharose Fast Flow column with a bed volume of $30 \mathrm{ml}$. The column was washed with $20 \mu \mathrm{M}$ Tris- $\mathrm{HCl}$ buffer $\mathrm{pH} 8.0$ at the flow rate of $1 \mathrm{ml} / \mathrm{min}$. Other proteins which bound to the column were then eluted by using linear salt gradient from 0.0-1.0 M sodium chloride at the same flow rate. The active fractions were pooled and concentrated by means of the centrifugal ultrafiltration with MW cut off at 10,000 and kept in an ice bath for the next step of enzyme purification.

Gel filtration chromatography. Gel filtration chromatography was used for the last step of enzyme purification. The Superdex 200 HR 10/30 column with 24 $\mathrm{ml}$ bed volume was pre-equilibrated with $50 \mu \mathrm{M}$ sodium phosphate buffer $\mathrm{pH} 7.0$ with $0.15 \mathrm{M}$ sodium chloride. The concentrated enzyme from the previous step was applied. The enzyme was eluted from the column with the same buffer at a flow rate of $0.5 \mathrm{ml} / \mathrm{min}$. Active fractions were determined for GLOD activity by the colorimetric method, and were pooled and concentrated for further assays.

\section{SDS-polyacrylamide gel electrophoresis}

SDS-PAGE slab gel was carried out using a MiniPROTEAN3 ${ }^{\circledR}$ cell (Bio-Rad, Hercules, USA). Molecular weight markers were obtained from Sigma-Aldrich Corp., St. Louis, USA. The gels were subjected to protein bands visualization with silver staining method.

\section{Molecular weight determination by gel filtration chromatography}

The relative molecular weight $\left(\mathrm{M}_{\mathrm{r}}\right)$ of the native enzyme was determined by using Superdex $200 \mathrm{HR}$ 10/30 column. Elution was done at the flow rate of $0.25 \mathrm{ml} / \mathrm{min}$ with an elution buffer comprising $50 \mu \mathrm{M}$ sodium phosphate buffer $\mathrm{pH} 7.0$ and $0.15 \mathrm{M} \mathrm{NaCl}$. The calibration curve was constructed using protein markers: cytochrome C $(12,400)$, carbonic anhydrase $(29,000)$, bovine serum albumin $(66,000)$, alcohol dehydrogenase $(150,000)$ and $\beta$-amylase $(200,000)$. Dextran blue $(2,000,000)$ and vitamin $\mathrm{B}_{12}$ $(1,355.4)$ were used to determine the void volume $\left(\mathrm{V}_{\mathrm{o}}\right)$ and total volume $\left(\mathrm{V}_{\mathrm{t}}\right)$, respectively. A calibration curve between $\log$ molecular weights of protein markers and the partition coefficient values, $\mathrm{K}_{\mathrm{av}}$, was constructed.

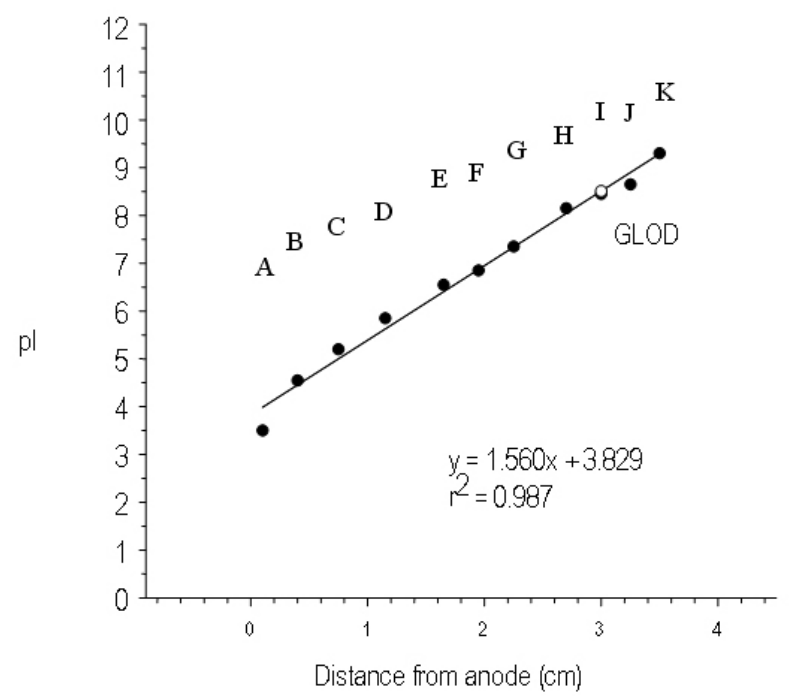

Figure 4. Isoelectric point determination of GLOD by isoelectric focusing. The standard pl markers were: $A$, amyloglucosidase (3.5); B, soybean trypsin inhibitor (4.55); C, blactoglobulin $A(5.20) ; D$, bovine carbonic anhydrase $B(5.85)$; $E$, human carbonic anhydrase B (6.55); F, myoglobin-acidic band (6.85); G, myoglobin-basic band (7.35); H, lentil lectin-acidic band (8.15); I, lentil lectin-middle band (8.45); J, lentil lectinbase band (8.65); K, trypsinogen (9.30). 

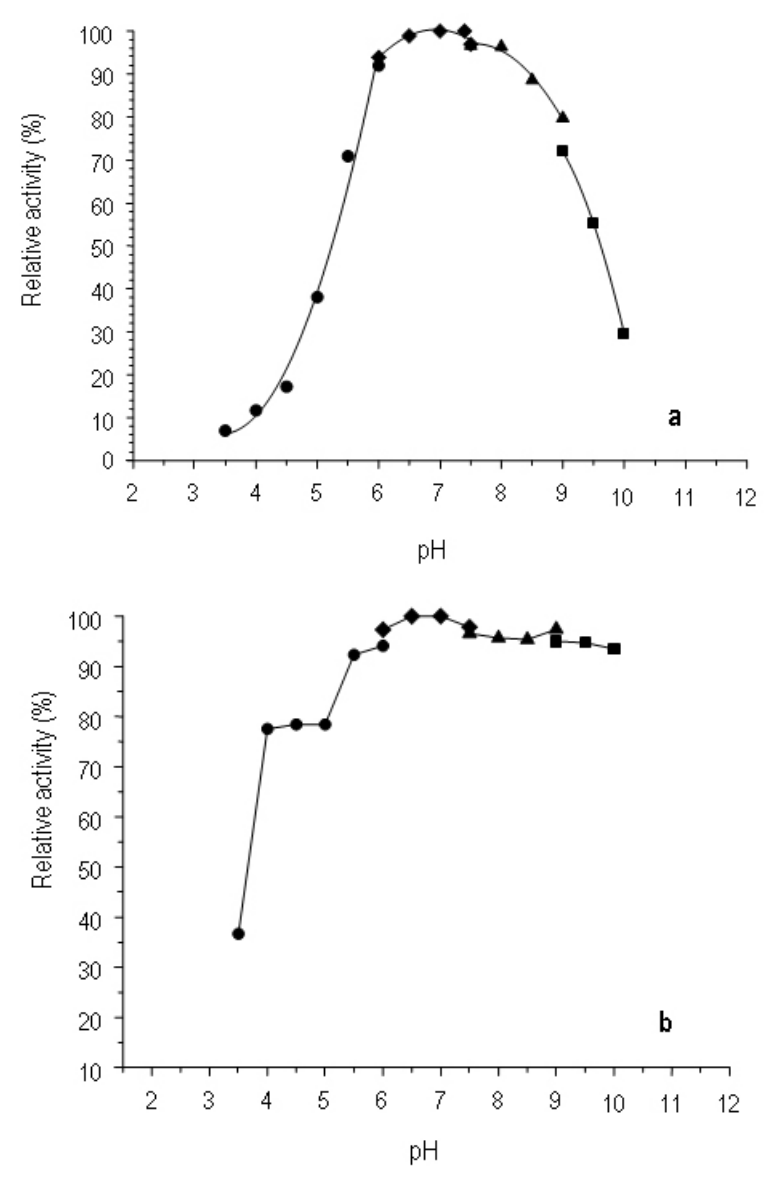

Figure 5. Effect of pH on GLOD activity (a) and stability (b).

(a) GLOD activity was assayed in various buffers with different $\mathrm{pH}$ values.

(b) (a) The enzyme was assayed in various buffers at different $\mathrm{pH}$ values by the method as described in the text.

(b) The enzyme was incubated in various buffers at the $\mathrm{pH}$ values indicated.

After incubation at $37^{\circ} \mathrm{C}$ for $30 \mathrm{~min}$, the remaining activities were determined by the method described in the text. The buffers $(0.1$ $\mathrm{M})$ used were: acetate buffer ( $\mathrm{pH} 3.5-6.0)(\mathrm{I})$, potassium phosphate buffer $(\mathrm{pH}$ 6.0-7.5) (u), Tris-HCl buffer $(\mathrm{pH}$ 7.5-9.0) (p), and glycine- $\mathrm{NaOH}$ buffer (pH 9.0-10.0) (n).

\section{Isoelectric point estimation}

The isoelectric point was determined by using PhastGel ${ }^{\hat{a}}$ IEF 3-9 (Amersham Biosciences, Uppsala, Sweden). The standard $\mathrm{p} I$ markers consisted of amyloglucosidase (3.5), soybean trypsin inhibitor (4.55), $\beta$-lactoglobulin A (5.20), bovine carbonic anhydrase B (5.85), human carbonic anhydrase B (6.55), myoglobin-acidic band (6.85), myoglobin-basic band (7.35), lentil lectin-acidic band (8.15), lentil lectin-middle band (8.45), lentil lectin-base band (8.65) and trypsinogen (9.30). Plots of the distances of the protein markers from the anode and their $\mathrm{p} I$ 's were constructed and fitted using linear regression. The $\mathrm{p} I$ of the GLOD was estimated using a regression equation.

\section{RESULTS}

\section{Enzyme production}

The extracellular GLOD was produced in wheat bran precultivation medium (Böhmer et al. 1989). GLOD activity obtained was $13.79 \mathrm{mU} / \mathrm{ml}$. The composition of the medium was modified to formulate the medium that promoted the higher GLOD production. The effect of MSG added in the medium to the GLOD productivity was also investigated. There was no improvement in the enzyme productivity by adding glucose as a carbon source. The optimal GLOD production medium containing $2.0 \%$ wheat bran, $0.5 \% \mathrm{NaCl}$ and $0.5 \%$ MSG was selected and named wheat bran medium. The maximum GLOD production was obtained from the cultivation of Streptomyces sp. $18 \mathrm{G}$ in wheat bran medium at $30^{\circ} \mathrm{C}$ for $60 \mathrm{hrs}$ with shaking at 200 rpm.

\section{Purification of GLOD}

GLOD was purified from an extract of Streptomyces sp. $18 \mathrm{G}$ cultured on wheat bran medium. The procedure included precipitation with ammonium sulphate, column chromatography on SP-SepharoseFF, Q-SepharoseFF and a high resolution gel filtration on Superdex 200 HR 10/30 as described above. Table 1 summarizes the purification of the enzyme. The overall purification was 990 fold with a yield of $16.65 \%$. The purified enzyme showed a single band in SDS-PAGE and had a specific activity of $152.35 \mathrm{U} \mathrm{mg}^{-1}$ (Figure 1).

\section{Molecular weight and subunit structure}

The relative molecular weight $\left(\mathrm{M}_{\mathrm{r}}\right)$ of the native enzyme was estimated to be approximately 120,000 by Superdex 200 HR 10/30 gel filtration chromatography (Figure 2). The subunit structure of the enzyme was analyzed by SDSPAGE in 3 different polyacrylamide separating gel concentrations, i.e. $10 \%, 12 \%$ and $14 \%$ using a $4 \%$ stacking gel. Molecular weight of the enzyme subunits calculated from the three regression equations at different gel concentrations were 59,816, 63,252 and 60,044, respectively (Figure 3). The molecular weight of the GLOD subunit was estimated to be 61,000 . Since the native enzyme was approximately twice the size of the enzyme subunit, the results suggested that the enzyme consisted of two identical subunits.

\section{Isoelectric point}

The isoelectric point of the purified GLOD was estimated to be 8.5 by isoelectric focusing (Figure 4 ).

\section{Optimal pH and pH stability}

Figure 5A shows the pH-activity profile of GLOD. The enzyme showed maximum activity in the $\mathrm{pH}$ range from 7.0 to 7.4. The enzyme was more stable in alkaline $\mathrm{pH}$ than in acidic $\mathrm{pH}$ (Figure 5B). 

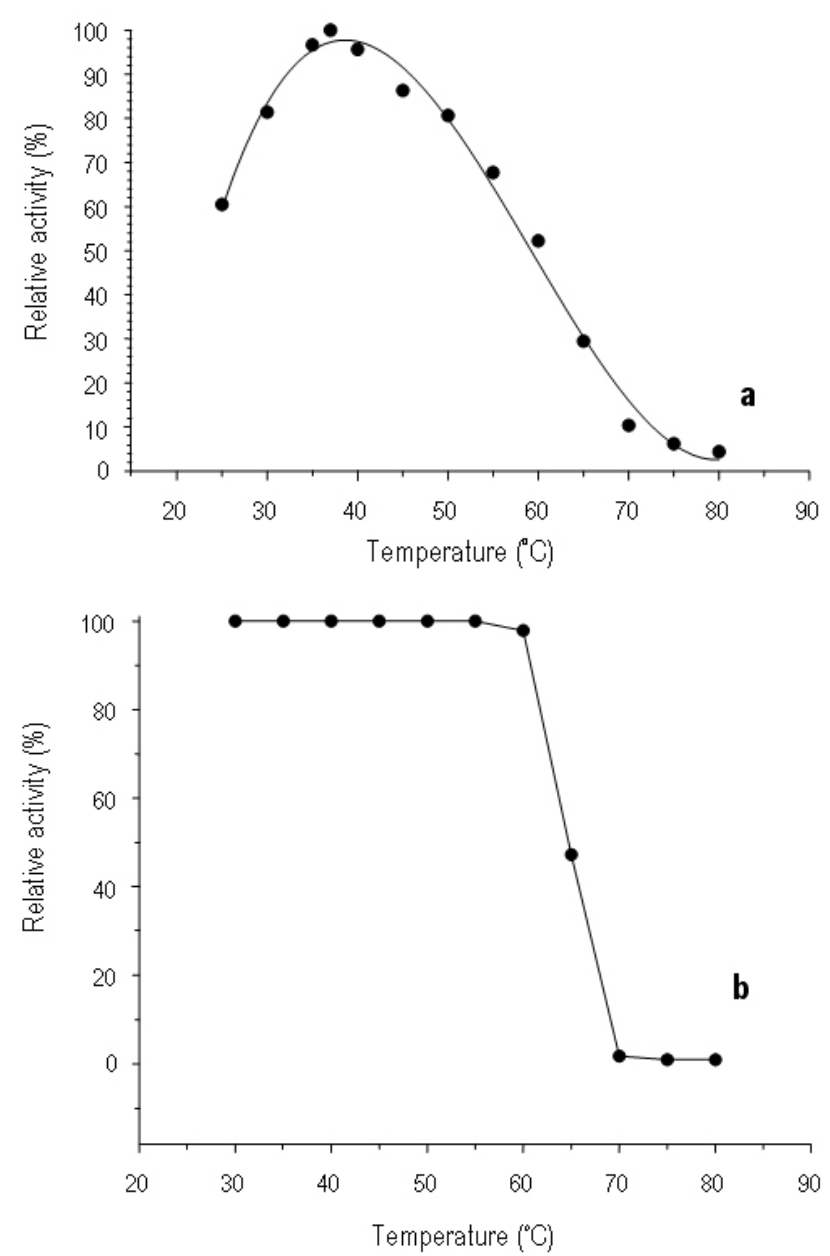

Figure 6. Effect of temperature on GLOD activity $(A)$ and stability (B).

(a) The enzyme activity was assayed at various temperatures by the method as described in the text.

(b) The enzyme was incubated in $0.1 \mathrm{M}$ potassium phosphate buffer $\mathrm{pH} 7.4$ at various temperatures for $1 \mathrm{hr}$. The residual activity was investigated by the method described in the text.

\section{Optimal temperature and thermal stability}

As illustrated in Figure 6A, GLOD activity showed maximum activity at $37^{\circ} \mathrm{C}$ under standard assay conditions described above. Thermal stability of GLOD was determined by incubating the enzyme in $0.1 \mathrm{M}$ potassium phosphate buffer $\mathrm{pH} 7.4$ at various temperatures for $1 \mathrm{hr}$. The enzyme was relatively stable from 30 to $55^{\circ} \mathrm{C}$. At $65^{\circ} \mathrm{C}$, the enzyme showed approximately $50 \%$ of the original activity. The enzyme was completely inactivated at $75^{\circ} \mathrm{C}$.

\section{Substrate specificity}

The activity of GLOD on various amino acids was investigated. Table 2 illustrates that L-glutamate was almost exclusively oxidized. In addition to L-glutamate, Dglutamate and L-aspartate were oxidized but with relative activities of $0.79 \%$ and $0.53 \%$, respectively. The activities on other amino acids tested were undetectable.

\section{DISCUSSION}

An extracellular GLOD was isolated from Streptomyces sp. 18G. The enzyme was efficiently produced in wheat bran medium. The enzyme was purified approximately 990 -fold from the culture broth with $16.65 \%$ yield. The specific activity was $152.36 \mathrm{U} \mathrm{mg}^{-1}$. The enzyme obtained in this study is different from those reported in previous studies in several aspects. The native enzyme has a molecular weight of approximately $120,000 \mathrm{Da}$ with 2 identical subunits. The results were in accordance with previous studies by Böhmer et al. 1989 and Patel et al. 2000. However, Kusakabe et al.1983 reported that GLOD from Streptomyces sp. X-119$6 \mathrm{had}$ a molecular weight of approximately $140 \mathrm{kDa}$ and consisted of 3 types of subunits, a, b and $g$ with molecular weights of approximately 44, 19 and $9 \mathrm{kDa}$, respectively. Recently, another GLOD with three subunits was obtained from S. platensis NTU3304 (Chen et al. 2001). The $\mathrm{p} I$ of GLOD from Streptomyces sp. $18 \mathrm{G}$ was estimated to be 8.5 which differed from those obtained from $S$. endus and Streptomyces sp. X-119-6 with $\mathrm{p} I 6.2$ in previous studies (Kusakabe et al. 1983; Böhmer et al. 1989). The pHactivity and temperature-activity profiles suggested that the optimal $\mathrm{pH}$ ranged from 7.0 to 7.4 and the optimal temperature was $37^{\circ} \mathrm{C}$, which is applicable for glutamate determination under physiological conditions. In addition, the enzyme shows almost exclusively oxidize L-glutamate with lower extent on other amino acids tested. However, a low GLOD production was obtained from Streptomyces sp. $18 \mathrm{G}$ in this study. This result implies that control of the culture conditions, i.e. $\mathrm{pH}$, salts, etc. may facilitate GLOD production. Arima and colleagues (2003) were successful in cloning and expressing the gene encoded for the enzyme in Escherichia coli. The report showed that proteolysis of the enzyme by metalloendopeptidase from Streptomyces griseus (Sgmp) could stabilize the recombinant enzyme and improvedits catalytic efficiency at various $\mathrm{pH}$. The report suggests that the DNA recombination technology can improve the GLOD production and stability.

Based on the results of this study, the GLOD from Streptomyces sp. 18G may have a potential for development of analytical systems for the specific determination of L-glutamate such as biosensors or kits for clinical diagnosis, bioprocess monitoring and food quality control. Additional studies are needed to obtain deeper insight into catalytic and physiochemical properties of the enzyme. Besides, molecular biology and bioprocess control may help promoting the production and stabilization of the enzyme.

\section{REFERENCES}

ALMEIDA, Nicholas F. and MULCHANDANI, Ashok K. A mediated ampermetric enzyme electrode using tetrathiafulvalene and glutamate oxidase for the determination of L-glutamic acid. Analytica Chimica Acta, 
October 1993, vol. 282, no. 2, p. 353-361.

ARIMA, Jiro; TAMURA, Takashi; KUSAKABE, Hitoshi; ASHIUCHI, Makoto; YAGI, Toshiharu; TANAKA, Hidehiko and INAGAKI, Kenji. Recombinant expression, biochemical characterization and stabilization through proteolysis of an L-glutamate oxidase from Streptomyces sp. X-119-6. Journal of Biochemistry, December 2003 vol. 134 , no. 6 , p. $805-812$.

BÖHMER, Annette; MÜLLER, Anita; PASSARGE, Margit; LIEBS, Peter; HONECK, Horst and MÜLLER, Hans-Georg. A novel L-glutamate oxidase from Streptomyces endus purification and properties. European Journal of Biochemistry, June 1989, vol. 182, no. 2, p. 327 332.

CHANG, Ku-Shang; HSU, Wen-Lin; CHEN, Hour-Young; CHANG, Chen-Kai and CHEN, Chien-Yuan. Determination of glutamate pyruvate transaminase activity in clinical specimens using a biosensor composed of immobilized -glutamate oxidase in a photo-crosslinkable polymer membrane on a palladium-deposited screenprinted carbon electrode. Analytica Chimica Acta, April 2003, vol. 481, no. 2, p. 199-208.

CHEN, C.Y.; WU, W.T.; HUANG, C.J.; LIN, M.H.; CHANG, C.K.; HUANG, H.J. et al. A common precursor for the three subunits of L-glutamate oxidase encoded by gox gene from Streptomyces platensis NTU3304. Canadian Journal of Microbiology, March 2001, vol. 47, no. 3, p. 269-275.

CHEN, Chien-Yuan and SU, Yuan-Chi. Amperometric Lglutamate sensor using a novel L-glutamate oxidase from Streptomyces platensis NTU 3304. Analytica Chimica Acta, 1991, vol. 243, p. 9-15.

COOPER, J.M. and PRITCHARD, D.J. Biomolecular sensors for neurotransmitter determination electrochemical immobilization of glutamate oxidase at microelectrodes in a poly(o-phenylenediamine) film. Journal of Material Science: Materials in Electronics, 1994, vol. 5, p. 111-116.

FUKUNAGA, Sadao; YUNO, Shinji; TAKAHASHI, Mitsuru; TAGUCHI, Susumu; KERA, Yoshio; ODANI, Shoji and YAMADA, Ryo-Hei. Purification and properties of D-glutamate oxidase from Candida boidinii 2201. Journal of Fermentation and Bioengineering, 1998, vol. 85, no. 6 , p. $579-583$.

HANKO, Valoran P. and ROHRER, Jeffrey S. Determination of amino acids in cell culture and fermentation broth media using anion-exchange chromatography with integrated pulsed amperometric detection. Analytical Biochemistry, January 2004, vol. 324, no. 1, p. 29-38.

HAYAKAWA, Masayuki and NONOMURA, Hideo.
Humic acid-vitamin agar, a new medium for the selective isolation of soil actinomycetes. Journal of Fermentation Technology, 1987, vol. 65, no. 5, p. 501-509.

KAMEI, Toshio; ASANO, Kasuko; SUZIKI, Hajime; MATSUZAKI, Meiki and NAKAMURA, Shoshiro. Lglutamate oxidase from Streptomyces violascens. I. Production, isolation and some properties. Chemical and Pharmaceutical Bulletin, April 1983, vol. 31, no. 4, p. 1307-1314.

KONDRAT, Richard W.; KANAMORI, Keiko and ROSS, Brian D. In vivo microdialysis and gaschromatography/mass-spectrometry for 13C-enrichment measurement of extracellular glutamate in rat brain. Journal of Neuroscience Methods, October 2002, vol. 120, no. 2, p. 179-192.

KUSAKABE, Hitoshi; MIDORIKAWA, Yuichiro; FUJISHIMA, Tetsuro; KUNINAKA, Akira and YOSHINO, Hiroshi. Purification and properties of a new enzyme, L-glutamate oxidase, from Streptomyces sp. X119-6 grown on wheat bran. Agricultural and Biological Chemistry, 1983 , vol. 47 , no. 6 , p. 1323-1328.

LI, Qingshan; WANG, Lijun and LI, Yourong. Color development with rational screening methods for improved L-glutamate oxidase-producing strains. Enzyme and Microbial Technology, January 1996, vol. 18, no. 1, p. 7-9.

LING, Daren; WU, Guoqi; WANG, Chen; WANG; Fan and SONG, Guoqiang. The preparation and characterization of an immobilized L-glutamic decarboxylase and its application for determination of L-glutamic acid. Enzyme and Microbial Technology, October 2000, vol. 27, no. 7, p. 516-521.

LIU, Zhiming; NIWA, Osamu; HORIUCHI, Tsutomu; KURITA, Ryoji and TORIMITSU, Keiichi. NADH and glutamate on-line sensors using Os-HRP/GC electrodes modified with NADH oxidase and glutamate dehydrogenase. Biosensors and Bioelectronics, October 1999, vol. 14, no. 7, p. 631-638.

MATSUMOTO, Kiyoshi; ASADA, Waka and MURAI, Reiko. Simultaneous biosensing of inosine monophosphate and glutamate by use of immobilized enzyme reactors. Analytica Chimica Acta, January 1998, vol. 358, no. 2, p. 127-136.

NIWA, Osamu; HORIUCHI, Tsutomu and TORIMITSU, Keiichi. Continuous monitoring of L-glutamate released from cultured nerve cells by an online sensor coupled with micro-capillary sampling. Biosensors and Bioelectronics, 1997, vol. 12, no. 4, p. 311-319.

OLIVEIRA, Maria Isaura P.; PIMENTEL, Maria Carmo; MONTENEGRO, Maria Conceição B.S.M.; ARAÚJO, Alberto N.; PIMENTEL, Maria F. and SILVA, Valdinete Lins da. L-Glutamate determination in food samples by 
flow-injection analysis. Analytica Chimica Acta, December 2001, vol. 448, no. 1-2, p. 207-213.

PATEL, Ramesh N.; BANERJEE, Amit; NANDURI, Venkata B.; GOLDBERG, Steven L.; JOHNSTON, Robert M.; Hanson, Ronald L.; McNAMEE, Clyde G.; BRZOZOWSKI, David B.; TULLY, Thomas P.; KO, Raphael Y., et al. Biocatalytic preparation of chiral synthon for a vasopeptidase inhibitor: enzymatic conversion of N2[(N-Phenylmethoxyl) carbonyl] L-homocysteinyl-1lysine(1-1')-disulfide to [4S-(4I,7I,10aJ)] 1-octahydro-5oxo-4-[(phenylmethoxy)carbonyl-amino]-7H-pyrido-[2,1-

b] $[1,3]$ thiazepine-7-carboxylic acid methyl ester by a novel L-lysine ?-aminotransferase. Enzyme and Microbial Technology, September 2000, vol. 27, no. 6, p. 376-389.

QHOBOSHEANE, Monde; WU, Donghai; GU, Yunrong and TAN, Weihong. A two-dimensional imaging biosensor to monitor enhanced brain glutamate release stimulated by nicotine. Journal of Neuroscience Methods, May 2004, vol. 135, no. 1-2, p. 71-78.

RODRIGUEZ, Belen Bello; BOLBOT, John A. and TOTHILL, Ibtisam E. Development of urease and glutamic dehydrogenase amperometric assay for heavy metals screening in polluted samples. Biosensors and Bioelectronics, May 2004, vol. 19, no. 10, p. 1157-1167.

SHI, Renbing and STEIN, Kathrin. Flow injection methods for determination of L-glutamate using glutamate decarboxylase and glutamate dehydrogenase reactors with spectrophotometric detection. The Analyst, 1996, vol. 121, no. 9 , p. 1305-1309.

UDOMSOPAGIT, Suchat, SUPHANTHARIKA, Manop, KÜNNECKE, Wolfgang, BILITEWSKI, Ursula, and BHUMIRATANA, Amaret. Determination of L-glutamate in various commercial soy sauce products using flow injection analysis with a modified electrode. World Journal of Microbiology and Biotechnology, 1998, vol. 14, p. 543549.

VALERO, Edelmira and GARCIA-CARMONA, Francisco. A continuous spectrophotometric method based on enzymatic cycling for determining L-glutamate. Analytical Biochemistry, 1998, vol. 259, no. 2, p. 265-271.

VILLARTA, Rhodora L.; CUNNINGHAM, David D. and GUILBAULT, George G. Amperometric enzyme electrodes for the determination of L-glutamate. Talanta, January 1991, vol. 38, no. 1, p. 49-55.

WHITE, S.F.; TURNER, A.P.F.; BILITEWSKI, U.; SCHMID, R.D. and BRADLEY, J. Lactate, glutamate, and glutamine biosensors based on rhodinized carbon electrodes. Analytica Chimica Acta, September 1994, vol. 295 , no. 3, p. 243-251.

WILLIAMS, S.T.; GOODFELLOW, M.; ALDERSON, G.; WELLINGTON, E.M.H.; SNEATH, P.H.A. and SACKIN,
M.J. Numerical classification of Streptomyces and related genera. Journal of General Microbiology, 1983, vol. 129, no. 6 , p. 1743-1813.

YAO, Toshio; SUZUKI, Seita; NAKAHARA, Taketoshi and NISHINO, Hirohito. Highly sensitive detection of Lglutamate by on-line amperometric micro-flow analysis based on enzymatic substrate recycling. Talanta, March 1998, vol. 45, no. 5, p. 917-923.

YE, Bang-Ce; LI, Qing-Shan; LI, You-Rong; LI, Xiao-Bo and YU, Jun-Tang. L-glutamate oxidase and its application to flow injection analysis system. Journal of Biotechnology, August 1995, vol. 42, no. 1, p. 45-52.

ZILKHA, E.; OBRENOVITCH, T.P.; KOSHY, A.; KUSAKABE, H. and BENNETTO, H.P. Extracellular glutamate-on-line monitoring using microdialysis coupled to enzyme- amperometric analysis. Journal of Neuroscience Methods, August 1995, vol. 60, no. 1-2, p. 1-9. 